\title{
GLOBAL WARMING: AN INCUBATOR OF DETERRITORIALIZED STATES
}

\author{
Franck Duhautoy*
}

According to the Romanian philosopher and writer, Emil Cioran (1911-1995), "We do not live in a country, we live in a language. A homeland is this and nothing else" . Following such logic, dominion over a territorial substratum is not very important from the perspective of allowing a group of people to identify themselves as sovereign. However, etymologically, the term territory comes from the Latin territorium meaning "an area in which a group of people live" ${ }^{2}$. Deprived of such territory, the unity of the human group originally residing there may therefore disappear. However, the nation state shows itself to be particularly flexible and capable of evolving according to the political challenges it faces ${ }^{3}$. To date, the transformations causing profound changes or the disappearance of States were the result of actions taken by other state entities. These transformations were the result of armed conflict, a conquest, a war of independence, a

* Doctor (Ph. D.) in Public Law, University of Nantes (France). Research laboratory member Law and Social Change, UMR CNRS 6297. Professor in the French high school of Warsaw.

1 E. Cioran, Aveux et anathèmes, Gallimard, Paris 1987, at p. 21.

2 A. Rey, Dictionnaire historique de la langue française, Le Robert, Paris, 1992.

3 Ch. Cournil, F. Gemenne, Les populations insulaires face au changement climatique: des migrations à anticiper, 'VertigO - la revue électronique en sciences de l'environnement', décembre 2010, vol. 10, no 3, Posted online 19.1.2011, page consulted 10.03.2015, URL : http://vertigo.revues.org/10482, at para 45. 
merger or a transfer... 4 . History has thus bequeathed the dissolution of a State via absorption by another, by the merger of two state entities, by reunification or by dissolution with the succession of one State to another. The effects of the present global warming generate a new scenario. Some island nation states see themselves threatened by the effects of the rising oceans. Their territories may soon become hostile to any use and to any decent human life. The question of the continuity of the bond of nationality for a population with an island state entity threatened with physically disappearance can legitimately be questioned. For the international society, the State is the ultimate legal subject. Its legal existence is verified when three elements are present ${ }^{5}$ : a population (the bond of nationality to the State), a territory (material support) and a Government exercising its authority in a fully sovereign way (independence) ${ }^{6}$. Do the physical submersion of an island State or the non-use of its inhospitable territory lead inevitably to its legal disappearance as state entity? There is no doubt that the rise of the oceans poses questions about the survival of the Westphalian States (1). However, the current deterritorialization of law and certain doctrinal elements allow us to imagine a mutation of States which would permit their survival as a matter of law despite the absence of an effective physical territory (2).

\section{Westphalian States threatened by global warming}

A famous advisory opinion of the Permanent Court of International Justice states that sovereignty is based on state independence, described as the exclusive right to take decisions regarding all economic, political, and financial matters. This opinion is described as based on the capacity to exercise such authority within State borders ${ }^{7}$. The exclusive right of decision-making and territory are therefore closely related, a clearly defined border appearing as a way to avoid any encroachment upon another

4 H. Ruiz-Fabri, Genèse et disparition de l'État à l'époque contemporaine, 'Annuaire français de droit international' 1992, vol. 38, at pp. 153-178.

5 These three components form the «status» of the State.

6 B. Chantebout, Droit Constitutionnel, $24 \mathrm{e}^{\mathrm{me}}$ éd, coll. Sirey Université, éd. Dalloz, Paris 2007, at p. 4.

7 Permanent Court of International Justice, Customs Regime between Germany and Austria, Advisory Opinion of 5.9.1931, SERIES A/B, N ${ }^{\circ}$ 41, at p. 12. 
sovereignty. This vision, stemming from the Treaties of Westphalia (1648), has been challenged by the gradual proliferation of transnational entities since the $19^{\text {th }}$ century (1.1). The current rise of the oceans resulting from global warming strengthens, unexpectedly, an evolution which was, at least initially, not physical but legal (1.2).

\subsection{Logic and calling into question the Westphalian law}

The 1648 treaties of Westphalia created an international law based on the sovereignty of States. They are the product of an intellectual maturation which commenced in previous decades. Thus, in 1576, in his work The Six Books of the Republic, the great French jurist Jean Bodin (1529-1596), set forth his reflection on public affairs and on the King's powers. This gave birth to the first legal theory about sovereignty. Jean Bodin defined it as "the absolute and perpetual power of a republic (...), [ $t$ ] hat is to say, the greatest power to order" ${ }^{8}$. For his part, the Dutchman Hugo Grotius (1583-1645) published in 1623 a book entitled De Jure Belli ac Pacis in which he proposed to establish a mutual society among nations to lay down the foundations of a public international law code. Alongside Jean Bodin, his writings gave birth to the so-called Westphalian system which is at the origin of contemporary international relations and which comprises the following concepts:

- The balance of power leading to give equal importance of any State, small or large?.

- The inviolability of national sovereignty ${ }^{10}$.

- The principle of non-interference in the affairs of another sovereign State ${ }^{11}$.

From the Treaties of Westphalia, a new actor succeeds therefore to the previous political fragmentation which existed under Christian universalism: the modern State. Contemporary international law takes its roots in a renunciation of the ideal of a superhuman, timeless and universal law spanning the territories which it ignores the existence of while sublimating

8 J. Bodin, Les six livres de la République, Imprimerie de Jean Tournes, Lyon, 1579, livre premier, chapitre VIII, at p. 85.

${ }^{9}$ Article CXXII of Munster treaty.

10 Article CXII of Munster treaty.

11 Article LXIV of Munster treaty. 
them. From this abandonment results the logic of the territorial registration of laws. The world is then organized on the basis that state entities become the primary subjects of international law, whose sovereignty must be respected by neighbouring powers pursuant to the Westphalian concept of respect for borders, guarantee of peace. International relations become inter-state relations. The Westphalia treaties marked the emergence of States' absolute sovereignty as a fundamental principle of international law. Europe became a set of States with specific borders recognized by their neighbours, within which the relevant prince or monarch exercised full sovereignty. Among the characteristics of these modern States are the creation of standing armies, the acquiescence of political elites and a common language as a factor of unity. Thereafter, the Westphalian principles favoured the emergence of the idea of a nation-state possessing, within its borders, a sovereign independence with an army, a currency, justice, police, culture and an economy allowing it to live as independently as possible.

The definition of a state entity was further refined in contemporary international law by the Montevideo Convention of 26.12.1933 on the Rights and Duties of States. Article 1 thereof specifies four essential elements: 'The state as a person of international law should possess the following qualifications: a permanent population; a defined territory; government; and capacity to enter into relations with the other states ${ }^{12}$. A fundamental clause was also added: 'The political existence of the state is independent of recognition by the other states ${ }^{13}$. This ultra-Westphalian legal provision paved the way for the emergence of multiple new large or small States to the point that, later, the United Nations felt the need to give birth to the concepts of internal and external sovereignty. To be recognized as sovereign, States must, therefore, exercise their power over populations residing within their territories without external constraint ${ }^{14}$. Internally, they have 'competence-competence', that is to say, the ability to organize themselves. Externally, they should receive recognition by other state entities composing the international system. A State is fully recognized as a subject of international law if it is entitled to the previous two points in which it is also subjected.

Long from the Treaties of Westphalia, the State was therefore the only subject of international law. However, from 1815, States have

12 Montevideo Convention on the Rights and Duties of States (1933), Article 1.

13 Montevideo Convention on the Rights and Duties of States (1933), Article 3.

14 This point disrupts the recognition of Palestine as a sovereign State. 
felt the need to unite in international organizations which, slowly, will reach the status of subjects of law. The UN constitutes one such example, as does the European Union and other international organizations which have become the subjects of legislation. Since the end of World War II, the proliferation of international treaties has, indeed, tended to nullify the Westphalian principles by developing massively military, economic, financial or legal interdependencies. The development of other spaces having a transnational dimension has deprived the national territory of its legal uniqueness and of full legislative and judicial sovereignty. New sovereignty structures appeared at several levels, with the territorial State being only one amongst others. Meanwhile, the Westphalian aspects of the UN Charter ${ }^{15}$ reusing themselves in the Montevideo Convention ${ }^{16}$ which prohibit any interference in the internal affairs of a State tended to be gradually erased. Based on some writings of Grotius ${ }^{17}$ but mainly on the reflections of a contemporary French philosopher, Jean-François Revel (1924-2006), a right of 'interference' was imagined ${ }^{18}$ with the aim of protecting civilian populations threatened by their own government. It recognizes the legal possibility for one or more States to violate the sovereignty of another pursuant to a mandate issued by a supranational authority. Thus, the UN Security Council can authorities the use of force if it detects a threat to peace and international security ${ }^{19}$. Such interventions, including those witnessed in Somalia (1992-1993) and Bosnia and Herzegovina (1995-2002), have sometimes been perceived as belonging to the right of interference. More recently, resolution 1973 (adopted 17.3.2011) of the UN Security Council seems to have followed such logic by authorizing Member States 'to take all necessary measures (...) to protect civilians and civilian populated

15 United Nations Charter, Article 2, 7: «Nothing contained in the present Charter shall authorize the United Nations to intervene in matters which are essentially within the domestic jurisdiction of any State».

16 Montevideo Convention on the Rights and Duties of States (1933), Article 8: "No state has the right to intervene in the internal or external affairs of another".

17 Grotius, On the Law of War and Peace, at Book II, Chapter XXV, VIII.

18 Humanitarian intervention.

19 Charter of United Nations (26.7.1945), Chapter VII: Action with respect to threats against peace, breaches of the peace and acts of aggression. See in particular Article 42 which states that the Security Council «may undertake, through air forces, sea or land, any action it deems necessary to maintain or restore peace and international security». 
areas under threat of attack in Libyan Arab Jamahiriya, ${ }^{20}$. Accordingly, the Westphalian principles are challenged. The concept of supranational character allows intervention in the territory of any State even against its will in order to establish global governance under ad hoc international organizations. Some lawyers and political analysts see this as a way for global powers to impose their worldview. In parallel with this legal questioning of the Westphalian order, there exists another - more physical - challenge to the territorially-orientated concept of a state.

\section{2 . The legal problems caused by the waters rising}

Numerous scientific studies have provided evidence of a rise in sea levels as a consequence of the massive emission of greenhouse gases in the atmosphere, the fruits of human activities ${ }^{21}$. According to the Montego Bay Convention ${ }^{22}$, an island (and therefore an island State) is defined as: 'a naturally formed area of land, surrounded by water, which is above water at high tide"23. However, it appears that with: ' $[t]$ he rise of the water level, atolls may be completely submerged, remaining in the form of some emergent rocks ${ }^{24}$. A rock is defined, according to Article 121 (3) of the aforementioned Convention, as a place which: 'cannot sustain human habitation or economic life of their own' with, as a consequence, 'no exclusive economic zone or continental shelf'. Therefore, the uninhabitable character and

20 See: S/ RES/1973 (2011), paragraph 4. The abstention of China and Russia does not prevent the resolution to be legally valid. Admittedly, Article 27-3 of the United Nations Charter requires, in theory, the agreement of all the permanent members of the Security Council for decisions not covering procedural matters but between UN members, it is become customary to consider abstention as consent.

${ }^{21}$ See for example: CNRS, La montée du niveau des mers, extrait de la Lettre du Changement global $n^{\circ} 19$ - Programme International Géosphère Biosphère (IGBP) Programme Mondial de Recherches sur le Climat (WCRP) - Programme International «Dimensions Humaines» (IHDP) - Diversitas - Earth System Science Partnership (ESSP), avalible at: http://www.cnrs.fr/cw/dossiers/dosclim1/biblio/pigb19/03_montee.htm (page consulted on 11.3.2015).

22 The United Nations Convention on the Law of the Sea (UNCLOS) called Montego Bay Convention (dated 10.12.1982) came into force on 16.11.1994 after ratification of the $60^{\text {th }}$ State.

23 Montego Bay Convention, Article 121 (1).

${ }^{24}$ H. Raimana Lallemant, L'apatridie climatique et la disparition d'État dans le pacifique Sud, 'Revue juridique polynésienne' 2009, at pp. 77-94. 
the new shape of the submerged island give rise to the following question: is there preservation of a sea zone and can it be considered as a territory to ensure the survival of a State? According to the Polynesian jurist Hervé Raimana Lallemant, that seems very difficult because sea zones refer more to the notion of space ${ }^{25}$. Whatever the modalities of the displacement of a population, it is possible to question the preservation of a status of statehood if the population is left without a viable territory that possesses a government and people are compelled to relocate. For the French internationalist Pierre-Marie Dupuy, in their international relations, governments in exile could not legally represent the State they were forced to leave, since they would lack the effective necessary control of a sovereign power ${ }^{26}$. As regarding the idea of a nomadic State, this cannot be conceived any more legally ${ }^{27}$. Indeed, the concept of tribal or national sovereignty, triumphant after the fall of the Roman Empire, has been gradually replaced by the feudal idea of a union between the right to control and possession of a territory ${ }^{28}$. The concept of sovereign State subsequently emerged from such territorial political power over a banal seigniory.

In light of the above arguments, Tuvalu ${ }^{29}$, often described as the state entity most threatened with submersion due to climate change, could quickly disappear of international concern. With a population but without a territory in which to apply effective legislative or judicial power, the State of Tuvalu could no longer exist, especially since its government should take into account the presence of the exogenous power of the State that hosted its nationals ${ }^{30}$. Thus, unless a state entity decides freely to transfer part of its territory to Tuvalu, its survival appears to be greatly compromised. This would be the first instance of the disappearance of a State

25 H. Raimana Lallemant, L'apatridie climatique et la disparition d'État dans le pacifique Sud, 'Revue juridique polynésienne' 2009, at p. 86 (footnote 33).

${ }_{26}$ P.-M. Dupuy, Droit international public, $9^{\mathrm{e}}$ éd, éd Dalloz, coll. Droit public \& Science Politique, Paris 2008, at p. 33.

27 P.-M. Dupuy, Droit international public, $9^{\mathrm{e}}$ éd, éd Dalloz, coll. Droit public \& Science Politique, Paris 2008, at p. 34.

${ }^{28}$ W. E. Hall, A Treatise on International Law, the Clarendon Press, Oxford 1890, at pp. 20-21.

${ }^{29}$ Currently member of the Commonwealth, the archipelago of Tuvalu seems populated from the first millennium BC. It became an independent State in 1978. Its nine atolls lie midway between Hawaii and Australia and are neighboring Kiribati and Fiji.

30 H. Raimana Lallemant, L'apatridie climatique et la disparition d'État dans le pacifique Sud, 'Revue juridique polynésienne' 2009, at p. 85. 
caused by global environmental change. Other island state entities may find themselves in a similar situation. These disappearances would produce very different consequences than a simple State succession, for example in matters of appropriations. Sovereignty embodied, indeed, in a State guaranteeing respect of any property. The national territory juxtaposes the public domain governed by the State entity and the private properties subject to the sovereign will of their owners. However, the property rights of individuals or of legal entities could hardly be preserved in their entirety against the backdrop of the physical disappearance of the state territory. Moreover, no other State could claim succession to Tuvalu's public goods, including maritime areas. Indeed, the flooding of its territory and its resulting uninhabitable character would no longer fulfil the conditions laid down in the Montego Bay Convention, ${ }^{31}$ which indicate that uninhabitable rock has no exclusive economic zone (Article 121, §3). Such a radical disappearance would generate other specific consequences, such as the inability of transfer public debts.

In terms of personal status, the physical disappearance of island nation States makes it impossible for citizens of the defunct entity to automatically acquire a new nationality, given the absence of any successor State. Consequently, the Tuvaluans would become stateless (climatic in this case). The famous judgment of the International Court of Justice in the Nottebohm case of 6.4.1955 represents the benchmark definition of nationality and states that nationality:

[i]s a legal bond having as its basis a social fact of attachment, a genuine connection of existence, interests and sentiments, together with the existence of reciprocal rights and duties. It may be said to constitute the juridical expression of the fact that the individual upon whom it is conferred, either directly by the law or as the result of an act of the authorities, is in fact more closely connected with

31 The United Nations Convention on the Law of the Sea (UNCLOS), also called Montego Bay Convention, is the international agreement that resulted from the third United Nations Conference on the Law of the Sea (UNCLOS III), which took place between 1973 and 1982. The Law of the Sea Convention defines the rights and responsibilities of nations with respect to their use of the world's oceans, establishing guidelines for businesses, the environment, and the management of marine natural resources. The Convention, concluded in 1982, came into force in 1994; a year after Guyana became the 60th nation to sign this treaty. In August 2013, 165 countries and the European Union had joined in the Convention. 
the population of the State conferring nationality than with that of any other State ${ }^{32}$.

Pursuant to that judgment, the nationality conferred by a State may not be invoked in the international order vis-à-vis other States if it is ineffective. However, this link could be considered broken if the personal and territorial jurisdiction of the State could no longer be actually performed in the case of submerged island nation States. In this regard, the creation of a climatic statelessness would condemn de facto the legal survival of these state entities ${ }^{33}$. A priori, it seems desirable not to develop such a notion because it would mean confirming the possible disappearance of States as a consequence of having been unable to legislate vigorously against global warming. Such a legal innovation seems thus double-edged ${ }^{34}$. Climatic statelessness, besides being undesired by the peoples of island States or their representatives, could paradoxically reduce the extent to which such persons are able to participate in international negotiations. Indeed, their voices would not be any more heard because a legal solution to their problem would already exist.

\section{Towards deterritorialized States?}

The French public law Professor Hélène Ruiz-Fabri recalls that 'the creation or disappearance of State are, from the perspective of international order, disturbances which international law opposes principles of resistance that only the effectiveness can overcome ${ }^{35}$. It is true that international law not only regulates the interactions between States but also creates States and supports them as a way of organizing the world ${ }^{36}$. From

32 International Court of Justice, Nottebohm Case (second phase), Judgement of 6.4.1955, ICJ Reports 1955, at p. 23.

33 It should be noted that the Geneva Convention of 1951 requires States Parties to accept refugees persecuted but not considering the case of climate refugees.

${ }^{34} \mathrm{~J}$. McAdam, Disappearing States, Statelessness and the Boundaries of International Law, [in:] J. McAdam (ed.), 'Climate Change and Displacement: Multidisciplinary Perspectives', Hart Publishing, Oxford 2012, at pp. 105-129.

${ }_{35} \mathrm{H}$. Ruiz-Fabri, Genèse et disparition de l'État à l'époque contemporaine, 'Annuaire français de droit international' 1992, vol. 38, at p. 161.

36 D.S. Koller, The End of Geography: The Changing Nature of the International System and the Challenge to International Law: A Reply to Daniel Bethlehem, 'European Journal of 
there, it becomes possible to imagine States which lack any territorial base. The corporate nature of state entities, but also the continued weakening of domestic legal systems, seem to facilitate this evolution (2.1). Meanwhile, the doctrine takes the idea of deterritorialized States, conception seeming to adapt to international legal developments (2. 2).

\subsection{Legal inviolability of States, different paths}

By its very nature, international law leads to the protection of each State. The past reveals even logics of protectorates in which a state entity has relied to another or to an international organization (as the UN). Traditional international law, however, must be questioned in light of the contemporary issue of island nation States threatened by the consequences of climate changes. This reflection must be based on the prism of main legal principles: the right of peoples to self-determination ${ }^{37}$, the right to territorial integrity, the sovereign equality of States ${ }^{38}$ and to non-interference ${ }^{39}$.

Echoing the dominant internationalist doctrine, university professors of Paris II, Jean Combacau and Serge Sur, state that the "corporate" nature of the State explains that it:

[i]s legally identical to itself from its foundation to its dissolution. (...) It is not altered by mutations that affect its 'constituent elements' (...) significant changes in the State have no effect on its legal identity: the change, in more or less, of the spatial bases and of the population of that territorial collectivity of the State draws only otherwise the outlines of the object on which international jurisdictions are recognized to it and introduces no discontinuity of its existence ${ }^{40}$.

International Law' 2014, vol. 25, no 1, at p. 28.

37 United Nations Charter, Article 1.2 and International Covenant on Civil and Political Rights on 16.12.1966, Article 1.1: 'All peoples have the right of self-determination. By virtue of that right they freely determine their political status and freely pursue their economic, social and cultural development'.

38 United Nations Charter, Article 2.1.

39 United Nations Charter, Article 2.7.

40 J. Combacau, S. Sur, Droit international public, Montchrestien, Lextenso édition, Paris 2008 at p. 230 and following. 
Also, theoretically, the failure of a component of the State does not necessarily result in the automatic loss of statehood, given the existence of a "presumption of continuity" of its living conditions. The state entity, therefore, does not cease to exist with the gradual fading of its territory ${ }^{41}$; public international law takes no account of the legal disappearance of a State. Currently only succession or, simply, continuation are possible. The state entity continues to exist despite the changes caused or suffered. Moreover, in certain domestic legal systems the principle of the continuity of public service exists, which can be conceived only through a permanent State. This principle has been recognized in France as having a constitutional value $(1979)^{42}$. A specialist in international refugees law, Jane McAdam, recalls also that contemporary international law does not require a minimum size of territory or even population to constitute a State ${ }^{43}$. Cases in which a state entity could disappear would be, for example, by its voluntary absorption by another State (through a plebiscite) or a merger with it. This would allow 'shipwrecked' to acquire a new nationality, otherwise, they could always be expelled from their host State without international law having anything to say about it ${ }^{44}$. Such assumptions imply that the successor State assumes control of the defunct entity allowing it, eventually, to recover its maritime area. There is never a situation of 'empty' State.

Meanwhile, the survival of a State without territory may also occur by default. It may, indeed, be based on the continued weakening of domestic systems in favour of a deterritorialized legal conception which empties state entities of their prerogatives. For anyone, attachment to a territory provides an answer to two key questions: his identity and the laws he must obey. However, currently, a phenomenon is observable which entails the detachment of laws from their roots and the disintegration of territorial legal systems under the combined effect of promoting personal laws but also universal laws. The existence of a territory is ultimately irrelevant, since the laws tend to be personalized to physical persons or to business entities. Curiously, while personal status was once characteristic of dictatorial regimes, it is now claimed in the name of individual freedoms. This

41 J. Combacau, S. Sur, Droit international public, $7^{\mathrm{e}}$ éd, éd Montchrestien, Paris 2006, at $\mathrm{p} 301$.

42 French Constitutional Council, Decision No. 79-105DC of 25.7.1979.

43 J. McAdam, 'Disappearing States', Statelessness and the Boundaries of International Law, 'UNSW Law Research Paper'2010, no 2010-2. Available at SSRN: http://ssrn.com/ abstract $=1539766$, at p. 8 (accessed on 12.3.2015).

44 J. McAdam, op. cit. 
notion of laws personalized to individuals progresses at the same time as the heterogeneity of populations grows through migrations facilitated by the transportation revolution. It is also supported by an ideological atmosphere more favourable to multiculturalism than to assimilation. Referring to human rights, this school of thought seeks to promote the choice of his personal status by each individual. Thus, the former Lord Chief Justice of England and Wales, Lord Nicholas Philips, basing his conclusions on the freedom for parties to submit their agreements to a law other than English law, has advanced the idea that power could be given in the UK to Islamic or rabbinical courts ${ }^{45}$.

Personal status also continues to grow in importance as regards trade. Liberties associated with free trade are invoked to allow investors to overcome the laws of a country and thereby extending the practice of 'forum shopping'. The Court of Justice of the European Union (CJEU) has, for example, recognized the right for a company to register in a State with less restrictive rules ${ }^{46}$. The existence of a domestic legal system based purely on territory has thus little sense in the contemporary world and it must give way to the economic dogma of globalization. Any legal limits impeding the free movement of capital, goods or provision of services are increasingly dismantled. With the sovereign State weakened by multiculturalist logics or present economic globalization, the fiction of the direct link between people and things is no longer possible. The bonds of personal dependences therefore reappear ${ }^{47}$. Just as formerly the dogma of the Catholic Church formerly considered itself to be universal and proclaimed its a-territoriality, the truth given to the laws of economic or history extends throughout the globe ${ }^{48}$. In the name of globalization, the logic of deterritorialized laws triumphs. The EU, for example, is fully engaged in questioning importance of territory, and defines itself as 'an area of freedom, security and justice ${ }^{49}$ with no discernible limit. It isn't any more characterized as a territorial entity with clearly identifiable boundaries. Significantly, the development

The Guardian of 4.7.2008.

46 Centros, Case C-212/97, CJEU judgment of 9.3.1999, ECLI:EU:C:1999:126, concl. La Pergola. Add. It is also possible to retain: Vicking, Case C-438/05, CJEU judgment of 11.12.2007, ECLI:EU:C:2007:772 (deducting from the freedom of establishment a right to use flags of convenience).

47 A. Supiot, L'inscription territoriale des lois, 'Esprit', novembre 2008, at p. 159.

48 A. Supiot, L'inscription territoriale des lois, 'Esprit', novembre 2008, at p. 153.

49 European Union, Amsterdam Treaty (1997), Article 1, 3. 
of a 'single market' entails the use, for the first time, of the notion ${ }^{50}$ of space in reference to the ground and not only to evoke the sky, the interstellar regions or the sea. This non-differentiation of locations goes hand in hand with the project of a global law, independent of territorial legal systems ${ }^{51}$. The unhindered flows triumph on places having the disadvantage to be delineated. By such logic, the existence of deterritorialized States can be imagined by default from the moment that the existence of territories no longer possesses the great importance it once did. The presence of state entities of this nature has already been theorized in academic writings.

\subsection{Promote deterritorialized States?}

The traditional status of refugees integrating with the nationality of their host country for a long period is not intended to apply to an entire nation driven from its home by global warming ${ }^{52}$. As regards ordinary people received in a scattered way, they will depend on the jurisdiction of the host State. From these two points does a negation of the right of nations to self-determination emerge, which remains a fundamental part of the International Covenant on Civil and Political Rights? ${ }^{53}$ To avoid this, the easiest solution would be to imagine the legal survival of island States despite the amputation of their territory. However, are other state entities ready to that? This, certainly, would contradict the Montevideo Convention, which defines a sovereign State as respecting the following four criteria: ' $[t]$ he State as a person of international law should possess the following qualifications: a permanent population; a defined territory; government; and capacity to enter into relations with the other States ${ }^{54}$. However, history has bequeathed the concept of dematerialized States such as, for example, the Sovereign Order of Malta. Despite lacking a territory

50 Term used by Alain Supiot, professor at the Collège de France.

51 G. Teubner, Global Law without a State, Dartmouth 1997, p. 305.

52 Among the most threatened nations, it is possible to mention that of the island State of Tuvalu spanning on 9 atolls among which 8 welcome 12,000 inhabitants.

53 International Covenant on Civil and Political Rights, Article 1.1. Island states, therefore, would have an interest to ratify this Convention. It is unfortunate that one of the States most threatened by global warming, Tuvalu, hasn't done it for reasons of lack of expertise. Perhaps the pro bono programs of a law firm could help.

54 Montevideo Convention on the Rights and Duties of States, Article 1. In international law, this treaty is often retained for its definition of a sovereign State. 
since the invasion of the island of Malta in 1798 by Napoleon Bonaparte (1804-1815), it is still perceived as a subject of international law. Indeed, despite its a-territoriality, it is recognized by 104 States in which it has a diplomatic representation. The same is true of the Council of Europe, UNESCO and the International Institute of Human Rights ${ }^{55}$. Currently, the seat of the Sovereign Order of Malta is located in Rome, where it enjoys an extraterritorial status.

The idea of deterritorialized States has been theorized in the AustroHungarian Empire at the turn of the $19^{\text {th }}$ and $20^{\text {th }}$ centuries. In The question of nationalities and social democracy (1907), the socialist thinker Otto Bauer (1881-1938) conceived the idea of renovating the Austro-Hungarian Empire through a national-cultural autonomy system for its various nationalities ${ }^{56}$. He proposed the creation of sub-state entities deterritorialized across the country. Otto Bauer saw this as a substitute to the dichotomy of assimilation-separatism. His writings, associated with those of another leader of the Austro-Hungarian Social Democracy of that time, Karl Renner (1870-1950), has helped to forge the idea of a State uniting several nations, unlinked by any territorial setting ${ }^{57}$. These two thinkers imagined it as based on public corporations, true national associations, in which those inhabitants who wished to adhere would do so. In return, these people would receive an official identity ${ }^{58}$. This conception is based on the principle, currently in vogue, of individual personal autonomy. Sub-state entities created would constitute extraterritorial legal persons which could issue passports, establish a government, use a specific language and send repre-

55 The Sovereign Order of Malta has also an observer's permanent seat at the United Nations. The list of States with which there are diplomatic and official relations is visible on line on the website address: http://www.orderofmalta.int/relations-diplomatiques/874/ordre-souverain-de-malte-relations-bilaterales/?lang=fr (accessed on 8.03.2015).

56 Marxist-Leninists didn't esteem Austrian socialists of that time (called austromarxists) they accused of 'revisionism'. This last political current has, subsequently, inspired Scandinavian social democracy.

57 For an analysis of the legal concept of nation, see an article of the French constitutionalist: St. Pierre-Caps, Karl Renner et l'Etat multinational. Contribution juridique à la solution d'imbroglios politiques contemporains, 'Droit et Société' 1994, vol. 27, at pp. 421-441.

58 See on this point: O. Bauer, The question of nationalities and the social democracy, vol. 2, Guerin Literature, Montreal, 1987, at p. 364: 'The principle of absolute personality seeks to constitute the nation not as a territorial corporation, but only as an association of persons.' 
sentatives to the common parliament of a super-State in order to defend their interests. The right to self-determination of the individuals would thus lead to internal self-administration of each sub-state entity coupled with codetermination in public affairs ${ }^{59}$. The right to be recorded in a nationality register would constitute a subjective right. Such a system, originally conceived to ensure the survival of the Austro-Hungarian Empire, can now be imagined on a global scale ${ }^{60}$. Deterritorialized sub-state entities sitting to the UN could thus emerge. Indeed, fundamentally, international law is not rooted in geography, but rather tends to create it under the form of ideas prevailing over the physical world ${ }^{61}$. This revolution of Westphalian law would save the sovereignty of the island States whose inhabitants are at risk of having to move because they lack a territory. Despite the loss of their islands, these States could legally survive without any territorial substratum by retaining their seats at the UN, symbols of the preservation of their exclusive political authority. Part of their resources would come from the survival of their maritime zones. The personal autonomy magnified by Karl Renner and Otto Bauer would therefore maintain the sovereignty of a population, albeit one which was deprived of territory and at risk of dispersion between host States.

Moreover, contemporary globalization makes it increasingly possible to imagine an evolution towards deterritorialized States. Indeed, the classic state territorial sovereignty is increasingly undermined by multinational firms which defend their investments by avoiding domestic judicial systems through international arbitration proceedings ${ }^{62}$. It is true that the transnational activities of these companies generate an inclusion between several States with, de facto, a problem of attributing responsibility. Further questions arise with the continuing development of cyberspace, wherein national judicial effectiveness appears unsuited to deal with computer servers located outside the territory of the State which may be involved in

59 K. Renner, Die Nation als Rechtsidee und Die Internationale, Wien, 1914, at p. 16.

${ }^{60}$ Karl Renner himself had also raised this point by speaking of creating a «national model for the future order of the universe.» See: K. Renner, Das Selbstbestimmungsrecht der Nationen (The right to self-determination of nations), Deuticke, Leipzig und Wien, at p. 36.

61 D. S. Koller, The End of Geography: The Changing Nature of the International System and the Challenge to International Law: A Reply to Daniel Bethlehem, 'European Journal of International Law' 2014, vol. 25, no 1, at pp. 27-28.

62 On this point, see: E. Cadeau, F. Duhautoy, Le droit à l'eau, soluble dans le droit international de l'investissement?, 'Droit de l'environnement' 2013, no 216, at pp. 338-343. 
allegations of non-compliance with local legislation. The current telecommunications revolution and its corollary (high capital mobility) coupled with the globalization of trade after the 1994 Marrakech Accords also leads to a deterritorialization of States. Gradually, the political and legal geography of territories is disintegrating before our eyes. To adapt themselves to present technical and economic evolutions, State should cease to limit themselves to the logic of sovereignty over a physical area, since this Westphalian conception seems currently to be in crisis ${ }^{63}$. The progressive gelatinization of political territories with the telecommunications revolution or the gradual disappearance of customs tariffs in the WTO makes likely a gradual evolution of the legal organization of States. Lawyers, inspired by Space Law, talk thus about building a state legal system based on the concept of activities as opposed to territories. Taking this path would completely undermine the running of public international law. Founding deterritorialized States is, nevertheless, difficult to imagine because it would open the door to all identity claims and would prove almost suicidal for existing state entities. On the other hand, the survival of the Sovereign Order of Malta enables us to imagine the possible preservation of sovereignty for a currently existing State which gradually loses its territory because of global warming. Its legal survival can occur, however, only if it manages to maintain a common cultural identity among its citizens that will probably be relocated in several host countries.

The triumphant Westphalian State with its borders closing a territory is no longer valid. It has been challenged by a motley coalition including international organizations, revolutions in transportation and telecommunications, courts of arbitration protecting foreign investments and also the commitment to promote multicultural human societies. The trend is such that some have imagined States without one of their constituent components: a defined territory. For state entities threatened by flooding which results from global warming, this is good news. The ubiquity of individuals permitted by the digital revolution portends a possible survival of the sovereignty of States which are little-by-little stripped of their territory. On the other hand, it seems rather premature to imagine a world with exclusively derritorialized States thriving on the remains of the Westphalian

63 The treaties of Westphalia in 1648 erected the principle of absolute sovereignty of the State in its territory at the expense of Christian unity as conceived in medieval times. They founded the international public order until our time. 
order. Even with sovereignty systems increasingly superimposed, the state entity remains a key player in the organization of the present world. The legal survival of those deprived of a territory does not mean the suicide of others by promoting exclusively deterritorialized States when physical evolution does not make this necessary. 